open Access

${ }^{1}$ Department of Organic Chemical Technology and Petrochemistry Silesian University of Technology, B. Krzywoustego Street 4, 44-100 Gliwice

\title{
Cannabidiol - characteristic and application in cosmetology and dermatology
}

\author{
Kannabidiol - charakterystyka i zastosowanie \\ w kosmetologii i dermatologii
}

\begin{abstract}
Cannabidiol (CBD) is one of the main active ingredients in hemp. It shows a number of valuable biological properties, such as anti-cancer, anti-depressant or anti-inflammatory.

The aim of the article was to present the most important properties of cannabidiol and its possible application in cosmetology and dermatology.

The wide therapeutic potential of CBD makes it possible to use in the treatment of, not only cancer or mental disorders, but also many dermatoses.
\end{abstract}

Keywords: cannabidiol, hemps, dermatology, pharmacological properties

\section{STRESZCZENIE}

Kannabidiol znany jako CBD, jest jednym z głównych składników aktywnych występujących w konopiach siewnych. Wykazuje szereg cennych właściwości biologicznych, m.in. działanie przeciwnowotworowe, przeciwdepresyjne czy przeciwzapalne.

Celem artykułu było zaprezentowanie właściwości oraz potencjalnego zastosowania kannabidiolu w kosmetologii i dermatologii.

Szeroki potencjał terapeutyczny CBD stwarza możliwość wykorzystania go w leczeniu nie tylko chorób nowotworowych czy zaburzeń psychicznych, ale wielu dermatoz.

Słowa kluczowe: kannabidiol, konopie siewne, dermatologia, właściwości farmakologiczne

\section{INTRODUCTION}

In recent years, there has been a significant increase in interest in natural cosmetics containing various raw materials of plant origin. These raw materials, which are a rich source of valuable active substances, are the motivation for the cosmetics industry. Due to the above, it is so important to search, discover, and then implement plants into the production of cosmetic preparations. Modern-day cosmetology appreciates components such as aloe, bakuchiol, honey, and bee products or spilanthol. Preparations based on hemp (Cannabis sativa L.) have also become popular and trendy. The cannabidiol known as CBD is of particular interest to scientists, manufacturers, and consumers alike. It has a number of valuable properties such as: anti-inflammatory and antioxidant, as well as anticancer, neuroprotective, and antipsychotic. It is the most abundant cannabinoid found in Cannabis sativa L., which, unlike $\Delta$ 9-tetrahydrocannabinol (THC), has no psychoactive effect. CBD draws attention due to its therapeutic potential and the possibility to 
use in the treatment of dermatoses (including atopic dermatitis, pruritus, psoriasis, acne), in anticancer and antidepressant therapies, or in the treatment of diabetes [1-4].

\section{CANNABINOIDS}

Cannabinoids, derived from dibenzopyrene or monoterpenoids, are a group of biologically active chemical substances that have been used in natural medicine for centuries [2]. Depending on the origin, there are three main categories:

1. endocannabinoids (ECB) synthesized by the human body, 2. phytocannabinoids (PCBs) obtained from plants,

3. synthetic cannabinoids (SC).

The chemical structures of selected endocannabinoids found in human skin and the structures of phytocanna- binoids most commonly found in cannabis are shown in Fig. 1 [5]. Cannabinoids are important mediators in the skin, but their role is not yet well understood and explained.

\section{CANNABIDIOL (CBD)}

Cannabidiol is one of over 100 phytocannabinoids (Fig. 1, 2) and is characterized by multidirectional biological activity. It poses anti-inflammatory, analgesic, antiepileptic, antiemetic and anxiolytic properties. It is obtained from the Cannabis sativa L. var sativa hemp, which, unlike the cannabis plant, contains less than $0.3 \%$ THC in dry weight, so it does not have psychoactive properties. Scientific research has proven that $\mathrm{CBD}$ has a positive, stimulating effect on the activity of the endocannabinoid system, which is the purpose of its great therapeutic potential.

\section{ENDOCANNABINOIDS}<smiles>C/C=C\C/C=C\C/C=C\C/C=C\CCCC(=O)NCCO</smiles>

Arachidonoyl Ethanolamide (AEA) Anandamid<smiles>CCCCC/C=C\C/C=C\C/C=C\C/C=C\CCCC(=O)OC(CO)CO</smiles><smiles>CC/C=C\C/C=C\C/C=C\C/C=C\C/C=C\CCCC(=O)NCCO</smiles><smiles>CCCCCCCCCCCCCCCC(=O)NCCO</smiles>

Palmitoyl Ethanolamide (PEA)<smiles>CCCCC/C=C\C/C=C\CCCCCCCC(=O)NCCO</smiles>

Linolenoyl Ethanolamide (LEA)

\section{PHYTOCANNABINOIDS}<smiles>C=C(C)C1CCC(C)=CC1c1c(O)cc(CCCCC)c(C(=O)O)c1O</smiles>

Cannabidiolic acid (CBDA)<smiles>CCCCCc1cc(O)c(C/C=C(\C)CCC=C(C)C)c(O)c1</smiles>

Cannabigerol (CBG)<smiles>C=C(C)C1CCC(C)=CC1c1c(O)cc(CCCCC)cc1O</smiles>

Cannabidiol (CBD)<smiles>CCCCCc1cc(O)c2c(c1)OC(C)(C)C1CCC(C)=CC21</smiles>

Tetrahydrocannabinol (THC)<smiles>CCCCc1cc(O)c2c(c1)OC(C)(C)C1(C)CCCC21</smiles>

Cannabinol (CBN)

Fig. 1. Chemical structures of selected cannabinoids Source: $[5,6]$ 


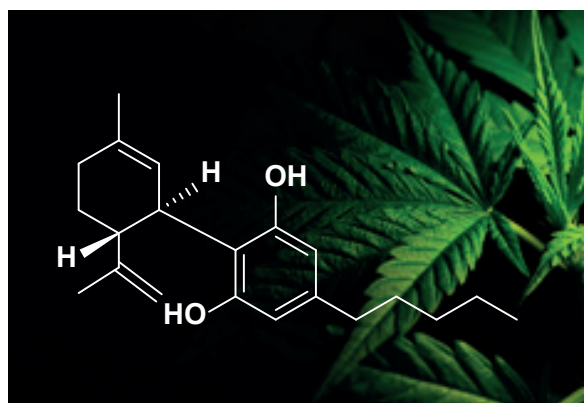

Fig. 2. The structure of cannabidiol Source: [7]

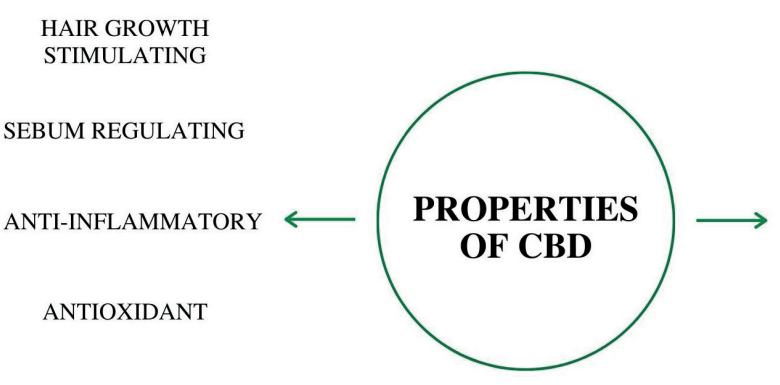

CYTOPROTECTIVE

NEUROPROTECTIVE

ANTI-STRESS

REDUCING INSOMNIA

ANTICANCER

ANTIBACTERIAL

Fig. 3. Properties of cannabidiol

Source: Own study

2-[(1R, 6R)-3-Methyl-6-(1-methylethenyl-2-cyclohexen1-yl]-5-pentyl-1,3-benzenediol (fig. 2, CAS: 13956-29-1, $\mathrm{C}_{21} \mathrm{H}_{30} \mathrm{O}_{2}, 314.464 \mathrm{~g} / \mathrm{mol}$ ) commonly known as cannabidiol (CBD) is an organic terpene-phenol compound of the absolute configuration (1R, 6R). Its structure includes a cyclohexene ring (A) and a phenolic ring (B) and a pentyl side chain. The hydroxyl groups are in the 1 and 3 positions of the phenolic ring, the methyl group in the 3-position of the cyclohexene ring. The pentyl chain exerts the greatest influence on the chemical activity and biological properties of CBD. In addition, the presence of hydroxyl groups makes it possible to combine CBD molecules, among others, with amino acids via hydrogen bonds [2].

\section{ENDOCANNABINOID SYSTEM}

The endocannabinoid system (ECS) consists of signalling molecules called endocannabinoids, specific receptors, and enzymes that are responsible for the production and degradation of endocannabinoids and endocannabinoid transporters. ECS regulates key processes and functions in the body (including body temperature, blood pressure, sleep quality, appetite, mental mood, energy management and pain perception). The best-known functions of ECS are related to the modulation of the central nervous system and the body's immune functions. Scientific research indicates the key role of ECS is in maintaining homeostasis and the skin's protective barrier [8].

The most important and best described are the cannabinoid receptor-1 (CB1R) and the cannabinoid receptor-2 (CB2R), which belong to the group of seven-transmembrane $\mathrm{G}$ protein-coupled receptors (GPCR) [8]. CB1R, associated mainly with the nervous system, are found in the tissues of the brain and spinal cord, but also in other organs like the heart, lungs, gastrointestinal tract. CB2R is characteristic of tissues related to the immune system (T-lymphocyte, spleen, tonsils). The aforementioned receptors are also found in the nerve fibers of the skin and its appendages [5, 9]. Their presence has also been proven in epidermal keratinocytes, hair follicles, or sebocytes in sebaceous glands [10]. In addition, cannabinoids can also bind to other receptors, inc- luding GPR-55, GPR-119, or TRPV-1, however, the interactions are not yet fully known [5]. By combining with CBR receptors present in the skin, cannabinoids cause a variety of biological effects, such as inhibition of epidermal keratinocyte proliferation, stimulation of epidermal keratinocyte differentiation, and anti-inflammatory effect. There is an ongoing discussion in the scientific literature about the role of the cannabinoid system in skin physiology and pathology. Scientists suggest the use of cannabinoids, including CBD, for atopic dermatitis, psoriasis, pruritus, acne, the excessive hair growth or loss, and hyper- or hypopigmentation [2, 8, 11-14].

\section{ANTI-INFLAMMATORY ACTION AND SEBUM REGULATION}

Several scientific studies confirm the anti-inflammatory effects of CBD, and the majority of them concern rheumatoid arthritis $[15,16]$. Promising reports contributed to research to assess the anti-inflammatory effect of CBD on human sebaceous gland cells. In 2014, Oláh et al. demonstrated that CBD prevents the increase in the concentration of cytokinins responsible for inflammation and inhibits the growth of sebaceous cells (in vitro and in vivo). In addition, researchers postulate that $\mathrm{CBD}$ can both quantitatively and qualitatively normalize the excessive and abnormal lipid production that often leads to the development of acne. Based on these reports, it is possible to conclude about the potential anti-acne effect of cannabidiol [17].

The anti-inflammatory effect of cannabidiol was also confirmed in 2018 by Italian scientists who showed that CBD inhibits the chemokines MCP-2 and other pro-inflammatory cytokines in keratinocytes. Moreover, it is more effective than other non-psychotropic phytocannabinoids used at the same dose. Thus, they suggested the potential use of CBD as an anti-allergic agent in dermatitis [18].

\section{ANTIBACTERIAL ACTION}

All cannabinoids exhibit relatively strong antibacterial properties. Research conducted on bacteria strains Staphylococcus aureus proves that $\mathrm{CBD}$ is one of the strongest inhibitors of cell growth found in cannabis and, as a non-psy- 
choactive substance, it is of particular interest [19]. There are also reports that $\mathrm{CBD}$ enhances the action of bacitracin against gram-positive bacteria [20].

\section{ANTI-OXIDATION ACTION}

Cannabidiol also exhibits antioxidant properties, which is probably related to the phenolic ring presence in the structure of this compound. It breaks the chain reactions leading to the formation of free radicals, traps or transforms them into less reactive forms, and also chelates transition metal ions involved in the Fenton reaction - prevents the formation of hydroxyl radicals. CBD also influences the level and the activity of other antioxidants [2, 21, 22].

Moreover, the first studies on the cytoprotective effect against UV-induced lesions and the potential use of CBD as an ingredient in UV protection preparations are emerging. The results obtained show that CBD influences cell viability by reducing the level of enzymes involved in protein degradation. It stimulates the production of enzymes involved in collagen cross-linking and prevents its degradation under the influence of UV radiation. It also reduces the expression of UV-induced metalloproteinases, thus preventing damage to the intracellular matrix and protecting structural proteins against a decrease in their expression caused by this radiation [23].

\section{HAIR GROWTH STIMULATION}

Clinical trials aimed at evaluating the effectiveness of the topical application of oil with a high concentration of CBD has shown the promising potential of this ingredient to support treatments of hair loss and thinning. These types of problems are associated with the increasingly common androgenetic alopecia (AGA). ECS receptors found in hair follicles are responsible for cell growth, controlling the phases of the hair growth cycle (anagen, catagen, and telogen phases). As a result of the interaction of CBD with the appropriate receptors, the shaft of the hair is elongated. A study by Szabó et al. on cultured hair follicle cells, showed that the use of lower doses of cannabidiol contributed to hair growth, while the use of higher doses of CBD resulted in an earlier entry into the catagen phase, which stops hair growth. Therefore, more detailed clinical trials are planned to determine the therapeutic dose. Nevertheless, cannabidiol is already assessed as a compound that, thanks to its properties and hair growth stimulating effect, will be treated as a complementary therapy in the pharmacological treatment of, among others, AGA [24].

\section{SUMMARY}

Natural hemp preparations have been used for thousands of years to heal wounds and skin lesions. Due to a number of interesting biological properties, there is more and more research on the potential use of CBD as an ingredi- ent in dermatological drugs or cosmetic preparations in the form of ointments, creams, or lotions. Notably, however, the overwhelming number of studies reported in the scientific literature concern the effects of CBD after ingestion, inhalation, or subcutaneous injection. There are relatively few reports of CBD's effects directly on human skin. Therefore, many of them do not consider pure cannabidiol. The effects of various types of hemp extracts or oils are often tested. The composition of such raw materials, both quantitative and qualitative, may vary depending on the diversity, stage of development, growing conditions or plant part. In addition to CBD, oils include other cannabinoids (e.g. cannabicyclol, cannabichromene, and dronabinol), constituting up to $20.7 \%$, monoterpenes ( $\alpha$ - and $\beta$-pinene, myrcene, limonene, $\beta$-caryophyllene), as well as sesquiterpenes and esters, alcohols, and ketones [25]. It has been shown that CBD is the main ingredient determining the anti-inflammatory activity of extracts and oils, but the remaining components of CSE (C. sativa ethanol extract) enhance this effect and additionally regulate the expression of genes responsible for the wound healing process [26, 27]. The popularity of cosmetics containing CBD is due to the phenomenon of the plant itself and appropriate marketing. Hemp is undoubtedly an unusual plant, and the therapeutic potential of CBD is extremely promising.

\section{ACKNOWLEDGMENTS}

This work was supported by Silesian University of Technology (Poland) Grant BK No. 04/050/BK_21/0116.

\section{REFERENCES / LITERATURA}

1. Khaksar S, Bigdeli MR. Intra-Cerebral Cannabidiol Infusion-Induced Neuroprotection Is Partly Associated with the TNF- $\alpha$ /TNFR1/NF-KB Pathway in Transient Focal Cerebral Ischaemia. Brain Inj. 2017;31(13-14): 1932-1943. https://doi.org/10.1080/02699052.2017.1358397

2. Atalay S, Jarocka-Karpowicz I, Skrzydlewska E. Antioxidative and Anti-Inflammatory Properties of Cannabidiol. Antioxid Basel Switz. 2019;9(1):E21. https://doi.org/10.3390/antiox9010021

3. Massi P, Vaccani A, Bianchessi S, et al. The Non-Psychoactive Cannabidiol Triggers Caspase Activation and Oxidative Stress in Human Glioma Cells. Cell Mol Life Sci CMLS. 2006;63(17):2057-2066. https://doi.org/10.1007/s00018-006-6156-x

4. Smeriglio A, Giofrè SV, Galati EM, et al. Inhibition of Aldose Reductase Activity by Cannabis Sativa Chemotypes Extracts with High Content of Cannabidiol or Cannabigerol. Fitoterapia. 2018;127:101-108. https://doi.org/10.1016/j.fitote.2018.02.002

5. Kupczyk P, Reich A, Szepietowski JC. Cannabinoid System in the Skin - a Possible Target for Future Therapies in Dermatology. Exp Dermatol. 2009;18(8):669-679. https://doi.org/10.1111/j.1600-0625.2009.00923.x

6. Baswan SM, Klosner AE, Glynn K, et al. Therapeutic Potential of Cannabidiol (CBD) for Skin Health and Disorders. Clin Cosmet Investig Dermatol. 2020;13:927-942. https://doi.org/10.2147/CCID.S286411

7. Brunetti P, Lo Faro AF, Pirani F, et al. Pharmacology and Legal Status of Cannabidiol. Ann Ist Super Sanita. 2020;56(3):285-291. https://doi.org/10.4415/ANN_20_03_06

8. Jeong S, Kim MS, Lee SH, Park BD. Epidermal Endocannabinoid System (EES) and Its Cosmetic Application. Cosmetics. 2019;6(2):33. https://doi.org/10.3390/cosmetics6020033

9. Ständer S, Schmelz M, Metze D, et al. Distribution of Cannabinoid Receptor 1 (CB1) and 2 (CB2) on Sensory Nerve Fibers and Adnexal Structures in Human Skin. J Dermatol Sci 2005;38(3):177-188. https://doi.org/10.1016/j.jdermsci.2005.01.007 
10. Tóth BI, Dobrosi N, Dajnoki A, et al. Endocannabinoids Modulate Human Epidermal Keratinocyte Proliferation and Survival via the Sequential Engagement of Cannabinoid Receptor-1 and Transient Receptor Potential Vanilloid-1. J Invest Dermatol. 2011;131(5):1095-1104. https://doi.org/10.1038/jid.2010.421

11. Karsak M, Gaffal E, Date R, et al. Attenuation of Allergic Contact Dermatitis through the Endocannabinoid System. Science. 2007; 316(5830): 1494-1497. https://doi.org/10.1126/science.1142265

12. Haruna T, Soga M, Morioka Y, et al. The Inhibitory Effect of S-777469, a Cannabinoid Type 2 Receptor Agonist, on Skin Inflammation in Mice. Pharmacology. 2017;99(5-6):259-267. https://doi.org/10.1159/000455916

13. Wilkinson JD, Williamson EM. Cannabinoids Inhibit Human Keratinocyte Proliferation through a Non-CB1/CB2 Mechanism and Have a Potential Therapeutic Value in the Treatment of Psoriasis. J Dermatol Sci. 2007;45(2):87-92. https://doi.org/10.1016/j.jdermsci.2006.10.009

14. Gaffal E, Cron M, Glodde N, et al. Cannabinoid 1 Receptors in Keratinocytes Modulate Proinflammatory Chemokine Secretion and Attenuate Contact Allergic Inflammation. J Immunol. 2013;190(10):4929-4936. https://doi.org/10.4049/jimmunol.1201777

15. Lodzki M, Godin B, Rakou L, et al. Cannabidiol-Transdermal Delivery and Anti-Inflammatory Effect in a Murine Model. J Control Release. 2003;93(3):377-387. https://doi.org/10.1016/j.jconrel.2003.09.001

16. Hammell DC, Zhang LP, Ma F, et al. Transdermal Cannabidiol Reduces Inflammation and Pain-Related Behaviours in a Rat Model of Arthritis. Eur J Pain Lond Engl. 2016;20(6):936-948. https://doi.org/10.1002/ejp.818

17. Oláh A, Tóth BI, Borbíró I, et al. Cannabidiol Exerts Sebostatic and Antiinflammatory Effects on Human Sebocytes. JClin Invest. 2014;124(9): 3713-3724. https://doi.org/10.1172/JCI64628

18. Petrosino S, Verde R, Vaia M, et al. Anti-Inflammatory Properties of Cannabidiol, a Nonpsychotropic Cannabinoid, in Experimental Allergic Contact Dermatitis. J Pharmacol Exp Ther. 2018;365(3):652-663. https://doi.org/10.1124/jpet.117.244368
19. Appendino G, Gibbons S, Giana A, et al. Antibacterial Cannabinoids from Cannabis Sativa: A Structure-Activity Study. J Nat Prod. 2008;71(8):1427-1430. https://doi.org/10.1021/np8002673

20. Wassmann CS, Højrup P, Klitgaard JK. Cannabidiol Is an Effective Helper Compound in Combination with Bacitracin to Kill Gram-Positive Bacteria. Sci Rep. 2020;10(1):4112. https://doi.org/10.1038/s41598-020-60952-0

21. Hamelink C, Hampson A, Wink DA, et al. Comparison of Cannabidiol, Antioxidants, and Diuretics in Reversing Binge Ethanol-Induced Neurotoxicity. J Pharmacol Exp Ther. 2005;314(2):780-788. https://doi.org/10.1124/jpet.105.085779

22. Peres FF, Lima AC, Hallak JEC, et al. Cannabidiol as a Promising Strategy to Treat and Prevent Movement Disorders? Front Pharmacol. 2018;9:482. https://doi.org/10.3389/fphar.2018.00482

23. Gęgotek A, Atalay S, Domingues P, Skrzydlewska E. The Differences in the Proteome Profile of Cannabidiol-Treated Skin Fibroblasts Following UVA or UVB Irradiation in 2D and 3D Cell Cultures. Cells. 2019;8(9):995. https://doi.org/10.3390/cells8090995

24. Smith G, Satino J. Hair Regrowth with Cannabidiol (CBD)-Rich Hemp Extract - A Case Series. Cannabis. 2021;4(1):53-59. https://doi.org/10.26828/cannabis/2021.01.003

25. Zheljazkov VD, Sikora V, Semerdjieva IB, et al. Grinding and Fractionation during Distillation Alter Hemp Essential Oil Profile and Its Antimicrobial Activity. Molecules. 2020;25(17):3943.

https://doi.org/10.3390/molecules25173943

26. Sangiovanni E, Fumagalli M, Pacchetti B, et al. Cannabis Sativa L. Extract and Cannabidiol Inhibit in Vitro Mediators of Skin Inflammation and Wound Injury. Phytother Res PTR. 2019;33(8):2083-2093. https://doi.org/10.1002/ptr.6400

27. Rossi P, Cappelli A, Marinelli O, et al. Mosquitocidal and Anti-Inflammatory Properties of The Essential Oils Obtained from Monoecious, Male, and Female Inflorescences of Hemp (Cannabis Sativa L.) and Their Encapsulation in Nanoemulsions. Molecules. 2020;25(15):3451. https://doi.org/10.3390/molecules25153451 